\title{
Recruiting a Diverse Group of Middle School Girls Into the Trial of Activity for Adolescent Girls
}

\author{
John P. Elder, PhD, MPH ${ }^{a}$, LaVerne Shuler, BE ${ }^{b}$, Stacey G. Moe, MPH ${ }^{C}$, Mira Grieser, MHS ${ }^{d}$, \\ Charlotte Pratt, $\mathbf{P h D}^{\mathrm{e}}$, Sandra Cameron, RN ${ }^{f}$, Melanie Hingle, RD, MPH ${ }^{9}$, Julie L. Pickrel, \\ MPH $^{h}$, Brit I. Saksvig, PhD, MHSi Kenneth Schachter, MD, MBAj, Susan Greer, MS ${ }^{\mathrm{k}}$, and \\ Elizabeth K. Guth Bothwell, MPH \\ aProfessor, (jelder@mail.sdsu.edu), Division of Health Promotion, Graduate School of Public \\ Health, San Diego State University, San Diego, CA 92182. \\ ${ }^{b}$ Research Associate/Program Manager, (ishuler@sc.edu), Health Sciences South Carolina, \\ Columbia, SC 29201.
}

'Coordinator, (moe@epi.umn.edu), Division of Epidemiology and Community Health, School of Public Health, University of Minnesota, Minneapolis, MN 55454.

dResearch Associate, (mgrieser@umd.edu), Department of Kinesiology, College of Health and Human Performance, University of Maryland, College Park, MD 20742.

eProgram Director, (prattc@nhlbi.nih.gov), National Heart, Lung, and Blood Institute, Division of Prevention and Population Sciences, MSC 7936, Bethesda, MD 20892.

fRecruitment and Measurement Coordinator, (scamerol@tulane.edu), Department of Biostatistics, School of Public Health and Tropical Medicine, Tulane University, New Orleans, LA 70112.

gResearch Associate, (hinglem@u.arizona.edu), Department of Nutritional Sciences, University of Arizona, PO Box 210093, Tucson, AZ 85721.

hProject Manager, (jpickrel@projects.sdsu.edu), Center for Behavioral and Community Health Studies, Graduate School of Public Health, San Diego State University, San Diego, CA 92123.

'Research Assistant Professor, (bsaksvig@umd.edu), Department of Epidemiology and Biostatistics, University of Maryland School of Public Health, RM 2316, SPH Bldg, College Park, MD 20742.

jProfessor, (kschacht@email.arizona.edu), Division of Community Environment and Policy, Mel and Enid Zuckerman College of Public Health, University of Arizona, Tucson, AZ 85724.

${ }^{k}$ Coordinator, (susan_greer@unc.edu), Department of Biostatistics, School of Public Health, University of North Carolina, Chapel Hill, NC 27514.

'Research Manager, (kbothwell@projects.sdsu.edu), Center for Behavioral and Community Health Studies, Graduate School of Public Health, San Diego State University, San Diego, CA 92123.

\section{Abstract \\ BACKGROUND—School-based study recruitment efforts are both time consuming and challenging. This paper highlights the recruitment strategies employed by the national, multisite Trial of Activity for Adolescent Girls (TAAG), a study designed to measure the effectiveness of an}


intervention to reduce the decline of physical activity levels among middle school—aged girls.

TAAG provided a unique opportunity to recruit large cohorts of randomly sampled girls within 36 diverse middle schools across the United States.

METHODS-Key elements of the formative planning, coordination, and design of TAAG's recruitment efforts included flexibility, tailoring, and the use of incentives. Various barriers, including a natural disaster, political tension, and district regulations, were encountered throughout the recruitment process, but coordinated strategies and frequent communication between the 6 TAAG sites were helpful in tailoring the recruitment process at the 36 intervention and control schools.

RESULTS-Progressively refined recruitment strategies and specific attention to the target audience of middle school girls resulted in overall study recruitment rates of $80 \%, 85 \%$, and $89 \%$, for the baseline, posttest, and follow-up period, respectively.

DISCUSSION-The steady increase in recruitment rates over time is attributed to an emphasis on successful strategies and a willingness to modify less successful methods. Open and consistent communication, an increasingly coordinated recruitment strategy, interactive recruitment presentations, and participant incentives resulted in an effective recruitment campaign.

\section{Keywords}

recruitment; TAAG; adolescent girls; school-based research; physical activity

Research efforts among children and adolescents in schools require careful attention to recruitment and retention rates. Recruiting students in school-based studies requires more than basic motivational efforts. One review of the literature ${ }^{1}$ summarizes methods for maximizing student participation in school-based research into 3 processes: (1) communication, (2) logistics, and (3) incentives. Harrington et $\mathrm{al}^{2}$ note that recruiting participants in school-based research requires a multilevel strategy directed at district, school, classroom, and individual levels. Direct contact with parents and strategies tailored to subpopulations add to the efficacy of recruitment activities. Additionally, the enlistment of an advocate at the district level, soliciting active support from teachers, and the use of incentives for both teachers and students all contribute to successful school-level recruitment efforts. Frye et $\mathrm{al}^{3}$ found that specific classroom assignment was the strongest determinant of participation among fourth graders in a nutrition study, indicating that teacher enthusiasm for a study may drive participation.

Recruitment efforts can be affected, first and foremost, by the method of recruitment selected. Passive recruitment strategies assume parental consent unless investigators receive a signed refusal from parents, whereas active recruitment strategies require express written permission of the parent to allow the child to participate. According to Eaton et al, ${ }^{4}$ active recruitment strategies can provide investigators with a definite indication of parental preferences that passive strategies cannot, but this is gained at the cost of greater monetary and temporal efforts. Minors or those below the age of 18 must also be given the opportunity to provide their permission, or assent, to participate. Given varying developmental stages, study information must be tailored to a child's developmental stage to obtain a valid informed assent. ${ }^{5}$

Research has shown that recruitment efforts are aided by the demonstration of caring on the part of professional staff, privacy and confidentiality, and altruism, as these characteristics increase the likelihood of study participation. ${ }^{6}$ Coday et $\mathrm{al}^{7}$ examined strategies among a 15site National Institutes of Health (NIH) Behavior Change Consortium to determine the most effective retention techniques for various target populations enrolled in trials. While they found that a loss of interest in the study, scheduling conflicts, lack of time to participate, competing demands for time, and transportation issues posed as significant barriers, they also noted that adolescents and children, in particular, respond well to incentives as a recruitment and retention strategy. 
According to Dickert and Grady, ${ }^{8}$ as cited by Rice and Broome, ${ }^{9}$ incentives can either be viewed as payment for the specific effort required for study participation, or as a financial reimbursement for expenses incurred by the child or family as a result of participation (eg, transportation). Nonmonetary incentives for youth in their preteen or teenage years include gift certificates, music CDs, tickets to concerts or other events, and movie passes. Rice and Broome ${ }^{9}$ recommend that incentives for children be proportional to the effort required of them, and that separate incentives should be offered to parents. However, Scherer et $\mathrm{al}^{10}$ caution that incentives may have a coercive effect as they found that the participants in their study of fair compensation for research trials actually suggested compensation in amounts less than what the researchers had proposed. Investigators therefore must balance the use of incentives to ensure that this compensation does not have a coercive effect on the participant, while also making certain that the incentive is relevant to the target population. ${ }^{11}$

Beyond incentives, study investigators must be flexible in their recruitment strategies to enable site-specific tailoring to meet the needs of potential participants and overcome unanticipated barriers. ${ }^{12}$ According to Kreiger et al, ${ }^{12}$ tailoring efforts should include (1) endorsement of project by a trusted and familiar person or agency, (2) facilitated group discussion regarding the consent process, and (3) clear communication of the benefits of participation to the participants being recruited. Recruitment experiences of the CATCH study ${ }^{10}$ reinforce that an important element in multisite trial recruitment is the flexibility to allow each site to tailor its recruitment approach to its own regional realities. This is further supported by McCormick et al, ${ }^{14}$ who note that recruitment strategies should be tailored to specific regions as variables such as culture and ethnicity differ from place to place.

Recruitment and retention strategies must be further tailored when recruiting minority or other hard-to-reach populations. Yancey et al ${ }^{15}$ conclude that personal contact is the most efficacious approach, especially for participants of lower socioeconomic status, whereas population-wide strategies may be ineffective in developing a diverse pool of participants. For inner city populations, 1 study indicated that staff flexibility, computer tracking, and face-to-face recruitment were essential elements in the recruitment of parents and children. ${ }^{16}$

Many of the aforementioned strategies were incorporated during recruitment for the 3 measurement phases of the Trial of Activity for Adolescent Girls (TAAG), a multicenter grouprandomized trial designed to test and evaluate an intervention to reduce the age-related decline in moderate to vigorous physical activity among middle school girls. ${ }^{17}$ To assess the effectiveness of the intervention, cross-sectional samples of girls were recruited for measurement/evaluation purposes at baseline, at posttest 2 years later (8A), and at follow-up 1 year after posttest (8B). TAAG provided a unique opportunity to recruit large cohorts of randomly sampled girls within diverse middle schools across the United States. This paper discusses the various recruitment strategies used as well as their respective successes and challenges, and serves as a useful reference for future school-based health behavior research.

\section{METHODS}

\section{Study Design}

Six universities were awarded cooperative agreements from the National Heart, Lung, and Blood Institute (NHLBI) to establish TAAG field centers in the vicinities of Washington, DC, and Baltimore, MD (University of Maryland); Columbia, SC (University of South Carolina); Minneapolis, MN (University of Minnesota); New Orleans, LA (Tulane University); Tucson, AZ (University of Arizona); and San Diego, CA (San Diego State University). The study's coordinating center was located at the University of North Carolina, Chapel Hill. The NHLBI project office also participated in the study. Each of the 6 field centers recruited 6 middle schools ( 36 schools total), which were randomly assigned to intervention or control conditions 
after baseline measurements were completed among sixth-grade girls. Schools within sites (rather than girls) were the unit of randomization ( 3 of the 6 per field center assigned to the intervention and the remaining 3 to the control condition), as the intervention emphasized changing school physical, social, and academic environments to support physical activity. ${ }^{17}$

\section{Across-Site Coordination of Recruitment Efforts}

Recruitment and investigator staff from all field sites met face-to-face at least annually and held conference calls on a monthly or more frequent basis. This coordinated interaction, along with regular email exchange, enabled investigators and staff to establish eligibility criteria, to develop a generic recruitment strategy, and to conduct problem-solving exchanges on sitespecific recruitment challenges.

\section{School Eligibility and Recruitment}

Public middle schools enrolling sixth through eighth graders, in which a majority of students lived in the surrounding community (ie, nonmagnet schools), were eligible to participate in TAAG. Additional school eligibility criteria included enrollment of at least 90 eighth-grade girls, yearly withdrawal rates of less than $28 \%$, physical education offered every semester with at least 1 semester of physical education required for each grade level, and willingness to sign a memorandum of understanding and to accept random assignment.

After identifying school districts and middle schools within driving distance (up to 100 miles) of the university-based field centers, sites searched public access data sources for schools that met these eligibility criteria. District superintendents were then contacted and presented lists of middle schools potentially eligible for the TAAG trial. With district permission, meetings were scheduled with the principals of these schools to present TAAG and enlist their participation. Recruitment continued until 6 schools per site (the desired number for each site, which resulted in a total sample of 36 schools) were enrolled in the trial. ${ }^{17}$ Of the 68 schools invited to participate, 41 agreed and 36 were ultimately selected based on the aforementioned inclusion criteria. Nonparticipating schools either did not respond to initial contacts or did not want to participate in a research trial. Across the 6 field sites, 19 school districts were represented. For the most part, TAAG schools represented the demographic and socioeconomic makeup of their districts, with site preference given to schools with greater racial/ethnic and socioeconomic diversity.

\section{Eligibility and Recruitment of Girls}

Random, cross-sectional samples of girls in each school were identified at baseline (when the first cohort of girls was in the sixth grade), 2-year posttest (when this same group was in the eighth grade, or 8A), and follow-up (with eighth-grade girls 1 year younger than the initial cohort, or $8 \mathrm{~B}$ ). School enrollment lists sent to the coordinating center by each field site were used to randomly select participants: 60 participants per school during baseline and 120 participants per school during $8 \mathrm{~A}$ and $8 \mathrm{~B}$. Both active parent consent and student assent were required for study participation. Students were excluded if they (1) could not complete TAAG questionnaires because of limited English reading and comprehension skills; (2) were not able to participate in physical education classes due to a medical condition or disability; and/or (3) had health, physical, or emotional problems or limited language abilities that would impair their ability to complete the TAAG questionnaires or participate in the physical fitness test, performed as an outcome measure during the $8 \mathrm{~A}$ measurement period. Each site made an effort to recruit at least $80 \%$ of the girls from the random sample at each school to participate in the measures that generally took place during school hours (however, participants were required to wear a physical activity monitor for a 7-day period, both during and outside of school hours). 
Given differences in the size of the schools and various circumstances, all girls in the grade were recruited for participation in small schools (enrollment of less than 120 eighth-grade girls), while at larger schools only the randomly selected girls plus a few randomly selected alternates, who were designated to replace any ineligible girls in the random sample, were recruited. When the size of the school was such that only a handful of girls would not be recruited, recruiting all eighth-grade girls was generally done for public relations purposes so girls did not feel excluded; however, data analyses only included data from the randomly selected girls.

The information for this report was collected from study documents designed to measure the different recruitment strategies employed by each site. A separate document was completed for each school for each of the 3 recruitment periods (baseline, 8A, and 8B) by recruitment coordinators or other project staff who played a pronounced role in the recruitment process. Information on race and socioeconomic status was obtained from school level data as well as participant self-report. Recruitment protocols were altered substantially from baseline (sixth grade) to $8 \mathrm{~A}$ (first eighth grade) cross sections in order to adjust for developmental differences in the older adolescent participants. Protocols were adjusted and tailored by some sites from the first (8A) to the second (8B) cross sections, especially by those sites seeking to improve their recruitment rates. Since the latter 2 cross sections comprise girls at the same educational and developmental levels and are in schools with multiyear rather than only initial (ie, baseline recruitment) exposure to the program, the present results focus on these latter 2 efforts.

\section{RESULTS}

Table 1 presents the recruitment results for all 3 time points, with an emphasis on the first (8A) and second $(8 \mathrm{~B})$ follow-up recruitment efforts.

Five of the 6 sites increased their overall recruitment rates between $8 \mathrm{~A}$ and $8 \mathrm{~B}$, while the most successful site (LA) in both cross sections evidenced a slight decrease in recruitment rates, from $97 \%$ and $95 \%$. Twenty-four of the 34 schools (reduced from 36 due to hurricane-related school closures at the LA site) remaining in the study at $8 \mathrm{~B}$ evidenced increased recruitment rates from $8 \mathrm{~A}$ to $8 \mathrm{~B}$, while 3 did not change and 7 showed decreases. Four of 6 sites exceeded the $80 \%$ recruitment criterion in $8 \mathrm{~A}$, increasing to 5 of the 6 sites in $8 \mathrm{~B}$, with all 5 actually exceeding $90 \%$ recruitment. In both $8 \mathrm{~A}$ and $8 \mathrm{~B}, 25$ of the 34 schools achieved the $80 \%$ recruitment rate. Three schools did not make the $80 \%$ recruitment rate in either $8 \mathrm{~A}$ or $8 \mathrm{~B}$, while 6 schools that did not achieve $80 \%$ recruitment in $8 \mathrm{~A}$ did reach the goal in 8B. Only 1 school that achieved $80 \%$ in $8 \mathrm{~A}$ failed to reach the goal again in $8 \mathrm{~B}$. Refer to Table 1 for site-specific recruitment rates and length of time spent recruiting participants.

\section{Recruitment Strategies}

Table 2 presents the recruitment strategies used and the degree to which they were incorporated by site for $8 \mathrm{~A}$ and $8 \mathrm{~B}$. A substantial range was evidenced in terms of the size, target, and type of incentives; logistics of returning consent forms; use of personnel; and communication strategies, as might be expected for such a diverse collection of regions and conditions. According to anecdotal recruitment reports, all incentives were generally well received by participants and were considered to be very effective in helping to accomplish recruitment goals. Recruitment props, skits, and presentations depicting the measurement activities were also thought to be effective. Logistically, setting a short turnaround time of 1 week for parents to return consent forms became a preferred strategy. Sites varied substantially in terms of other strategies. For example, some sites displayed their recruitment progress on the walls of their research offices to motivate recruitment and measurement staff. One site used telephone prompts to encourage parents to return consent forms, whereas other sites thought that this direct method could result in a backlash among target parents. 


\section{Unanticipated Challenges and Subsequent Adjustments}

Strategies were developed and continuously refined, as anticipated changes (such as the move from sixth- to eighth-grade participants between baseline and 8A) as well as unforeseen circumstances arose. Although the anticipated changes typically affected all field centers, unanticipated recruitment challenges were experienced by AZ, LA, MD, and SC. The following case studies detail specific recruitment strategies used to overcome those circumstances (MD, SC) and the impact of the unforeseen circumstances on participant recruitment (LA, AZ).

Maryland made significant changes to their recruitment strategy between baseline and $8 \mathrm{~A}$ measurement periods, increasing recruitment from $74 \%$ to $88 \%$. The key changes accounting for this improvement included (1) staggering recruitment, with sequential 2-week recruitment efforts in 2 schools at a time, which allowed for more focused and intensive efforts in each school; (2) paying a teacher a small stipend to act as a recruitment liaison and follow-up with girls when TAAG staff were not on campus; (3) conducting small group recruitment presentations instead of large assemblies; (4) offering a \$50 mall gift certificate as the participant incentive for completing all general measurements (height, weight, skin fold, valid accelerometer, and 2 physical activity-related surveys) rather than gift bags consisting of token items; (5) shortening the consent form (a study-wide change) and explaining the study more simply during recruitment visits; (6) conducting a focus group with eighth-grade girls opinion leaders (as identified by teachers) at the school with the lowest recruitment rate at baseline to assess their perception of TAAG and correct any misperceptions; and (7) ensuring that recruitment staff were friendly, energetic, and consistent.

South Carolina improved its overall recruitment rate from $75 \%$ in $8 \mathrm{~A}$ to $90 \%$ in $8 \mathrm{~B}$. To accomplish this, recruitment staff went from a 6 schoolwide effort over 9 months to an intensive 2-week school-by-school sequential approach in $8 \mathrm{~B}$. A colorful flyer highlighting measures and incentives, trendy (but clean) music at the beginning and end of the presentation, a decorative display board, and consent form drop boxes also boosted recruitment rates. In addition, $8 \mathrm{~B}$ parents were offered a $\$ 10$ incentive for returning the signed consent forms, regardless of their decision. This played a major role in the improved recruitment rate.

Following Hurricane Katrina in 2005, 2 LA TAAG schools did not reopen due to extensive damage. Some students from the 4 remaining TAAG schools were dispersed to other schools, while new students, unfamiliar with the TAAG project, were enrolled in the existing TAAG schools. Initially, investigators feared that students and staff in the 4 schools would be disinterested in the TAAG project and that $8 \mathrm{~B}$ enrollment numbers would suffer. However, TAAG staff followed the same strategies and procedures used during the baseline and $8 \mathrm{~A}$ measurement periods, making even more visits to each school, and developing relationships with new students. Over time, the students responded positively to TAAG visits, and students and staff alike seemed to welcome the renewal of the measurement effort as a part of a return to normalcy. The recruitment coordinator worked alone during the entire recruitment process, possibly making it easier to establish relationships with the girls and the school staff. In the end, LA achieved an overall $8 \mathrm{~B}$ recruitment rate of $95 \%$ in its 4 remaining schools.

Arizona was challenged by several logistical issues around incentives and school staff support, which may have adversely impacted recruitment rates. Undocumented immigrants comprise an estimated $40 \%$ of parents in 2 of the $6 \mathrm{AZ}$ schools, and they may have been less likely to sign a consent form asking for their personal contact information. Varying levels of teacher buy-in and support and the extended absence of a key school liaison were also problematic. Arizona also encountered university and school district restrictions on the use of incentives. Although cash was the preferred incentive among girls, university regulations initially required the collection of social security numbers for all cash incentives or checks over $\$ 20$. Historically, it has been difficult to collect social security numbers in AZ schools possibly because of the 
fear of identity theft and, as noted above, the presence of large numbers of undocumented immigrants in some schools. In addition, 1 school district's policy forbade the use of gift cards during $8 \mathrm{~A}$ recruitment. As a result, $\mathrm{AZ}$ investigators used gift items or gift cards when allowed as incentives, despite the fact that these incentives were not as salient among girls in the targeted population.

\section{Recruitment Successes}

The geographical separation of the field centers contributed to the ethnic and socioeconomic diversity of the girls recruited into the TAAG trial. As shown in Table 3, a diverse sample of girls was recruited during each study period, with Hispanics and blacks comprising an average of $22 \%$ and $21 \%$ of the sample, respectively. In addition, $38 \%$ of study participants (based on an average of data from baseline, $8 \mathrm{~A}$, and $8 \mathrm{~B}$ ) were eligible for the free-reduced price lunch program.

\section{DISCUSSION}

Similar to previous studies of recruitment for school-based trials, ${ }^{1,7,15,16}$ TAAG investigators found that specific techniques were key to our success. Age-appropriate incentives of sufficient value, whether they be in the form of cash, gift certificates, or other reinforcers, were central to achieving recruitment goals. ${ }^{1,7,9}$ These incentives were most effective in eliciting study participation, but even further in getting signed consent and assent forms (either agreeing or refusing to participate) returned. The fact that there were comparable recruitment rates in sites that offered different monetary amounts supports the literature in this area, ${ }^{1,7,9}$ in that it is necessary to provide incentives, but dollar amounts should be appropriate to sites'

circumstances. ${ }^{12,13}$ Regardless of the dollar value, the type of incentive must be age appropriate and relevant to the target population. As previously mentioned, TAAG sites worked to make appropriate adjustments throughout the study periods to address this.

Attention to the particular age-related nuances of TAAG participants was also important in creating rapport with students. For example, the use of "clean" popular music during the recruitment presentation by several sites may have helped to create a socially desirable atmosphere. In addition, TAAG's decision to recruit all girls in some schools reflects attention to the middle school-age preoccupation with social group affiliation and likely prevented feelings of exclusion.

Coordinated strategies were also central to the overall recruitment approach, with focused, sequential, school-by-school recruiting (and frequent follow-up of absentees or nonreturned forms) proving more effective than a more diffuse concurrent effort across all schools. As presaged by Yancey et al, ${ }^{15}$ establishing and maintaining relationships with school personnel and girls alike was critical to success, as was explaining the consent and measurement procedures to the girls with a grade level—appropriate short skit demonstration of the equipment that was to be used (eg, exercise bike, accelerometer, and skin fold calipers). Not all school personnel were supportive of TAAG, however, and this may have limited recruitment success in some schools.

Another challenge was presenting the study in a way that appealed to all girls regardless of their activity level. By $8 \mathrm{~A}$ and $8 \mathrm{~B}$ recruitment, TAAG intervention activities had been running for 1.5 to 2.5 years in the experimental condition, and it was sometimes challenging to differentiate between intervention and measurement activities in ways that the girls could easily understand. For example, the TAAG intervention encouraged girls to be active, whereas the message of TAAG measurement promoted participation regardless of physical activity level or interest. 
In other schools and sites, unforeseen circumstances also arose, including a hurricane of historically destructive proportions and the reluctance of undocumented parents to engage in formal consenting procedures in a climate of heightened tension over immigration. In most schools, recruitment rates were directly proportional to recruitment efforts. However, in some schools, despite a high level of recruitment effort, recruitment rates remained stubbornly low.

Anecdotal reasons for refusal as indicated on standardized site recruitment reports completed by the field centers included issues regarding inadequate incentives, unwillingness to wear the accelerometer, lack of peer support, and general time constraints. Some girls stated that they were either already active or uninterested in physical activity (thus misunderstanding what they were being recruited to do) and declined to enroll in the trial. These reasons for refusal were similar to those encountered by Coday et $\mathrm{al}^{7}$ except that in our case, the girls did not seem to lose interest in the study. This was perhaps due to TAAG's sampling method, using repeated cross sections rather than a longitudinal design. Other girls were unable to obtain parental permission, even if they themselves wanted to participate. This may have been due in part to the use of active consent procedures which required greater involvement on the part of parents. ${ }^{4}$ In all, however, with $80 \%$ (baseline), 85\% (8A), and 89\% (8B), TAAG realized high studywide rates of recruitment among all subgroups of middle school girls and equaled or exceeded target rates of $80 \%$ for adequate statistical power. ${ }^{17}$ While this sample is not fully representative given the school recruitment criteria and the potential resultant exclusion of lower income schools, the study population was drawn from public schools with diverse samples that are reflective of the national population.

In general, the recruitment of adolescents in research is challenging because there are so many factors that may affect their willingness to participate. As many teachers, researchers, and parents know, popularity and acceptability of activities among peers can be determined by mere nuance in presentation, making it difficult to identify reasons for success or failure of recruitment in a research trial like TAAG. School staff, teacher, and administrator enthusiasm for a project along with their history of cooperation with parents are among the many less tangible factors that may influence recruitment, as are university policies and researchers' experience, both individually and as a team. Here we have attempted to identify some common themes underlying successes and challenges in TAAG's recruitment experiences, while recognizing that recruiting adolescent girls can sometimes be more art than science.

\section{Acknowledgments}

This research was funded by grants from the National Heart, Lung, and Blood Institute. Grant numbers: U01HL066858, UOIHL066857, U011HL066845, U01HL066856, U01HL066855, UOIHL066853, and U01HL066852. The authors acknowledge Jennifer Reeves for her contributions to the manuscript. The authors also thank the study staff, including project coordinators and measurement staff, the schools, parents, and sixth- and eighth-grade girls at the participating middle schools.

\section{REFERENCES}

1. Ross JG, Sundberg EC, Flint KH. Informed consent in school health research: why, how, and making it easy. J Sch Health 1999;69(5):171-176. [PubMed: 10363220]

2. Harrington KF, Binkley D, Reynolds KD, et al. Recruitment issues in school-based research: lessons learned from the High 5 Alabama Project. J Sch Health 1997;67(10):415-421. [PubMed: 9503347]

3. Frye FH, Baxter SD, Thompson WO, Guinn CH. Influence of school, class, ethnicity, and gender on agreement of fourth graders to participate in a nutrition study. J Sch Health 2002;72(3):115-120. [PubMed: 11962227]

4. Eaton DK, Lowry R, Brener ND, Grunbaum JA, Kann L. Passive versus active parental permission in school-based survey research. Eval Rev 2004;28:564-577. [PubMed: 15486161] 
5. Lindeke LL, Hauck MR, Tanner M. Practical issues in obtaining child assent for research. J Ped Nurs 2000;15:99-104.

6. Stanford PD, Monte DA, Briggs FM, et al. Recruitment and retention of adolescent participants in HIV research: findings from the REACH (Reaching for Excellence in Adolescent Care and Health) Project. J Adolesc Health 2003;32(3):192-203. [PubMed: 12606113]

7. Coday M, Boutin-Foster C, Goldman ST, et al. Strategies for retaining study participants in behavioral intervention trials: retention experiences of the NIH Behavior Change Consortium. Ann Behav Med 2005;29(2 suppl):55-65. [PubMed: 15921490]

8. Dickert N, Grady C. What's the price of a research subject? Approaches to payment for research participation. N Engl J Med 1999;341:198-203. [PubMed: 10403861]

9. Rice M, Broome ME. Incentives for children in research. J Nurs Scholarsh 2004;36(2):167-172. [PubMed: 15227765]

10. Scherer DG, Brody JL, Annett RD, Hetter J, Roberts LW, Cofrin KMW. Financial compensation to adolescents for participation in biomedical research: adolescent and parent perspectives in seven studies. J Ped 2005;146:552-558.

11. Singer E, Bossarte RM. Incentives for survey participation; when are they coercive? Am J Prey Med 2006;31:411-418.

12. Kreiger N, Ashbury F, Cotterchio M, Macey JI. A qualitative study of subject recruitment for familial cancer research. Ann Epidemiol 2001;11(4):219-224. [PubMed: 11306339]

13. Lytle LA, Johnson CC, Bachman K, et al. Successful recruitment strategies for school-based health promotion: Experiences from CATCH. J Sch Health 1994;64(10):405-409. [PubMed: 7707715]

14. McCormick LK, Crawford M, Anderson RH, Gittelsohn J, Kingsley B, Upson D. Recruiting adolescents into qualitative tobacco research studies: experiences and lessons learned. J Sch Health 1999;69(3):95-99. [PubMed: 10332644]

15. Yancey AK, Ortega AN, Kumanyika SK. Effective recruitment and retention of minority research participants. Annu Rev Public Health 2006;27:1-28. [PubMed: 16533107]

16. Senturia YD, McNiff MK, Baker D, et al. Successful techniques for retention of study participants in an inner-city population. Control Clin Trials 1998;19(6):544-554. [PubMed: 9875834]

17. Stevens J, Murray DM, Catellier DJ, Hannan PJ, Elder JP, Young DR, Simons-Morton DG, Webber LS. Design of the Trial of Activity in Adolescent Girls (TAAG). Contemp Clin Trials 2005;26(2): 223-233. [PubMed: 15837442] 
Table 1

Recruitment Time Period* and Rates for the Baseline and First (8A) and Second (8B) Follow-Up Periodst ${ }^{\dagger}$

\begin{tabular}{|c|c|c|c|}
\hline Site & Baseline Recruitment Rate & 8A Recruitment Rate & 8B Recruitment Rate \\
\hline $\mathrm{AZ}$ & $\begin{array}{l}\text { Time period: } 4 \text { months, } \mathrm{N}=253(360), \\
\text { overall = 70\%; by school-A: } 68 \%, \\
\text { B: } 67 \%, \mathrm{C}: 72 \%, \mathrm{D}: 70 \%, \mathrm{E}: 68 \%, \mathrm{~F}: 77 \%\end{array}$ & $\begin{array}{l}\text { Time period: } 6 \text { months, } \mathrm{N}=491(664), \\
\text { overall }=74 \% \text {; by school- } \mathrm{A}^{+}: 68 \%, \\
\text { Bł: } 64 \%, \mathrm{C}: 81 \%(90), \mathrm{D}^{+}: 79 \%(98), \\
\text { E: } 68 \%, \mathrm{~F}: 86 \%(116)\end{array}$ & $\begin{array}{l}\text { Time period: } 6 \text { months, } \mathrm{N}=498(661), \\
\text { overall }=75 \% \text {; by school- } \mathrm{A}^{+}: 81 \%(108), \\
\text { B } \neq: 77 \%, \mathrm{C}: 68 \%(95), \mathrm{D}^{\ddagger}: 75 \%(101), \\
\text { E: } 69 \%, \mathrm{~F}: 81 \%\end{array}$ \\
\hline CA & $\begin{array}{l}\text { Time period: } 2.5 \text { months, } \mathrm{N}=311(360) \\
\text { overall }=86 \% \text {; by school-A: } 87 \%, \\
\text { B: } 85 \%, \text { C: } 92 \% \text {, D: } 82 \%, \text { E: } 92 \%, F: 82 \%\end{array}$ & $\begin{array}{l}\text { Time period: } 7 \text { months, } \mathrm{N}=596(675), \\
\text { overall }=88 \% \text {; by school-A: } 86 \%, \\
\mathrm{~B}^{+}: 89 \%, \mathrm{C}^{+}: 99 \%(91), \mathrm{D}: 78 \%, \\
\mathrm{E}+: 97 \%, \mathrm{~F}: 83 \%(104)\end{array}$ & $\begin{array}{l}\text { Time period: } 6 \text { months, } \mathrm{N}=670(705), \\
\text { overall = 95\%; by school-A: } 97 \%, \mathrm{~B}^{\dagger}: 95 \%, \\
\mathrm{C}^{\ddagger}: 98 \%(114), \mathrm{D}: 93 \%, \mathrm{E}^{\ddagger}: 98 \%, \mathrm{~F}: 89 \%(111)\end{array}$ \\
\hline LA & $\begin{array}{l}\text { Time period: } 4.5 \text { months, } \mathrm{N}=311(360) \\
\text { overall }=86 \% \text {; by school-A: } 85 \%, \\
\text { B: } 78 \%, \text { C: } 85 \% \text {, D: } 93 \%, \text { E: } 85 \%, F: 92 \%\end{array}$ & $\begin{array}{l}\text { Time period: } 5 \text { months, } \mathrm{N}=615(632), \\
\text { overall }=97 \% \text {; by school- } \mathrm{A}^{+}: 98 \%, \\
\text { B }: 100 \%(90), \mathrm{C}: 99 \%, \mathrm{D}: 95 \%(105), \\
\text { E: } 98 \%(117), \mathrm{F}^{+}: 91 \%(80)\end{array}$ & $\begin{array}{l}\text { Time period: } 3 \text { months, } \mathrm{N}=376(395), \\
\text { overall }=95 \% \text {; by school- } \mathrm{A}^{+}: 98 \%, \\
\text { B }: \text { N/A, C: N/A, D: } 96 \%(114), \\
\text { E: } 95 \%(87), F^{+}: 91 \%(74)\end{array}$ \\
\hline MD & $\begin{array}{l}\text { Time period: } 6 \text { months, } \mathrm{N}=265(360) \\
\text { overall }=74 \% \text {; by school-A: } 67 \%, \\
\text { B: } 70 \%, \text { C: } 80 \% \text {, D: } 83 \% \text {, E: } 58 \%, \mathrm{~F}: 83 \%\end{array}$ & $\begin{array}{l}\text { Time period: } 9 \text { months, } \mathrm{N}=633(720) \text {, } \\
\text { overall = 88\%; by school-A: } 87 \% \text {, } \\
\text { B: } 88 \%, \mathrm{C}^{+}: 85 \%, \mathrm{D}: 93 \%, \mathrm{E}^{+}: 85 \% \text {, } \\
\mathrm{F}+: 90 \%\end{array}$ & $\begin{array}{l}\text { Time period: } 8 \text { months, } \mathrm{N}=661(720) \text {, } \\
\text { overall = 92\%; by school-A: } 91 \% \text {, } \\
\text { B: } 88 \%, \mathrm{C}^{+}: 97 \%, \mathrm{D}: 90 \%, \\
\mathrm{E}+: 91 \%, \mathrm{~F}^{+}: 94 \%\end{array}$ \\
\hline $\mathrm{MN}$ & $\begin{array}{l}\text { Time period: } 5 \text { months, } \mathrm{N}=283(360) \\
\text { overall }=79 \% \text {; by school-A: } 68 \%, \\
\text { B: } 80 \%, \text { C: } 75 \%, \mathrm{D}: 93 \%, \mathrm{E}: 72 \%, \mathrm{~F}: 83 \%\end{array}$ & $\begin{array}{l}\text { Time period: } 8 \text { months, } \mathrm{N}=637(720) \\
\text { overall }=88 \% \text {; by school-A: } 88 \% \text {, } \\
8: 91 \%, \mathrm{C}^{\dagger}: 92 \%, \mathrm{D}: 85 \%, \mathrm{E}^{\dagger}: 90 \%, \mathrm{~F}^{\dagger}: 85 \%\end{array}$ & $\begin{array}{l}\text { Time period: } 7 \text { months, } \mathrm{N}=648(714) \text {, } \\
\text { overall = 91\%; by school-A: } 93 \% \text {, } \\
\text { B: } 88 \%, \mathrm{C}^{+}: 96 \%, \mathrm{D}: 89 \%(114), \\
\mathrm{E}+: 92 \%, \mathrm{~F}^{+}: 87 \%\end{array}$ \\
\hline $\mathrm{SC}$ & $\begin{array}{l}\text { Time period: } 5 \text { months, } \mathrm{N}=298(360) \\
\text { overall }=83 \% \text {; by school-A: } 83 \%, \\
\text { B: } 80 \%, \text { C: } 82 \% \text {, D: } 82 \% \text {, E: } 82 \%, \mathrm{~F}: 88 \%\end{array}$ & $\begin{array}{l}\text { Time period: } 9 \text { months, } \mathrm{N}=532(712) \text {, } \\
\text { overall }=75 \% \text {; by school- } \mathrm{A}^{+}: 73 \%(119) \text {, } \\
\text { B: } 72 \%, \mathrm{C}^{+}: 75 \%, \mathrm{D}^{+}: 62 \%, \mathrm{E}: 85 \%(113), \\
\text { F: } 83 \%\end{array}$ & $\begin{array}{l}\text { Time period: } 3 \text { months, } \mathrm{N}=648(720), \\
\text { overall }=90 \% \text {; by school- } \mathrm{A}^{+}: 89 \%, \\
\text { B: } 85 \%, \mathrm{C}^{+}: 93 \%, \mathrm{D}^{+}: 91 \%, \mathrm{E}: 90 \%, \mathrm{~F}: 93 \%\end{array}$ \\
\hline Overall & $\begin{array}{l}\text { Time period: } 4.5 \text { months, } \mathrm{N}=1721(2160) \text {, } \\
\text { overall }=80 \%\end{array}$ & $\begin{array}{l}\text { Time period: } 7.3 \text { months, } \mathrm{N}=3504(4123) \text {, } \\
\text { overall }=85 \%\end{array}$ & $\begin{array}{l}\text { Time period: } 5.5 \text { months, } \mathrm{N}=3501(3915) \text {, } \\
\text { overall }=89 \%\end{array}$ \\
\hline
\end{tabular}

* Time period from start of recruitment until the date on which the very last recruitment documentation was collected.

${ }^{\dagger} \mathrm{N}=$ study enrolled sample size (size of eligible random sample); size of eligible random sample at each school was 120 unless otherwise noted (may be smaller due to lower enrollment numbers or ineligibility).

† Control schools. 
Table 2

Overall Key TAAG Recruitment Strategies

\begin{tabular}{|c|c|c|c|}
\hline Strategy & $\mathbf{8 A}$ & $8 B$ & Rating* \\
\hline \multicolumn{4}{|l|}{ Recruitment procedure/strategy } \\
\hline TAAG recruitment staff & Varied by site: $1-9$ staff members & Varied by site: $1-9$ staff members & 3 \\
\hline \multirow[t]{3}{*}{ Recruitment staff training } & Informal meetings: AZ, CA, MD, SC & Informal staff meetings: AZ, MD & 2 \\
\hline & Informal meeting with train the trainer model: MN & IInformal meeting with train the trainer model: MN & 2 \\
\hline & Formal staff training: None & Formal staff training: CA, SC & 2 \\
\hline $\begin{array}{l}\text { Recruitment at school registration and } \\
\text { open houses }\end{array}$ & Yes: MD, MN (all schools), SC & Yes (\# of schools/site): AZ (5), CA (1), MN (4) & 1 \\
\hline $\begin{array}{l}\text { Solicit input and feedback from school } \\
\text { principals and liaisons }\end{array}$ & Yes: AZ, SC & Yes: AZ, SC & $\mathrm{AZ} 2 ; \mathrm{SC} 1$ \\
\hline Identify school liaison to assist staff & $\begin{array}{l}\text { Yes: AZ (popular staff member), CA (volunteer), } \\
\text { MD and SC (designated by principal) }\end{array}$ & $\begin{array}{l}\text {,Yes: AZ (popular staff member), CA (volunteer), } \\
\text { MD and SC (designated by principal) }\end{array}$ & 2 \\
\hline $\begin{array}{l}\text { Live in-school presentation to potential } \\
\text { participants }\end{array}$ & All sites & All sites & 3 \\
\hline \multirow[t]{3}{*}{ Presentation group size } & Small groups (10-20 girls): LA, MD & Small groups (10-20 girls): LA, MD & 3 \\
\hline & Class size (20-40 girls): AZ (5 schools), CA & Class size (20-40 girls): AZ (5 schools) & 3 \\
\hline & Entire eighth-grade class: CA, AZ (1 school) & Entire eighth-grade class: CA, AZ (1 school) & 2 \\
\hline Props used during presentation & $\begin{array}{l}\text { Consent form packet, measurement devices, } \\
\text { incentive display, posters/banner; site-specific } \\
\text { additions-recruitment skit: LA }\end{array}$ & $\begin{array}{l}\text { Additions to } 8 \text { A recruitment efforts—recruitment } \\
\text { visit } \\
\text { incentive: } \mathrm{MD} \text {; trivia game with prizes to } \\
\text { winning team: } \\
\text { CA; balloons: SC; school-approved "cool" } \\
\text { music: CA, SC }\end{array}$ & 3 \\
\hline Recruitment—prize drawing & SC: $1 \$ 100$ gift card per school & $\begin{array}{l}\text { AZ: } 1 \text { gift }(\$ 100) \text { per school; SC: } 3 \text { gifts (valued } \\
\text { from } \\
\quad \$ 100-\$ 120) \text { per school }\end{array}$ & $\mathrm{AZ} 2 ; \mathrm{SC} 1$ \\
\hline $80 \%$ recruitment goal party & $\begin{array}{l}\text { AZ: BBQ at } 1 \text { school; "No-Uniform" Day at } \\
\text { another; } \\
\text { SC: ice-cream sundae party at } 2 \text { schools }\end{array}$ & Dropped at $8 \mathrm{~B}$ & $\mathrm{AZ} 2 ; \mathrm{SC} 1$ \\
\hline General measurement incentive ${ }^{\dagger}$ & $\begin{array}{l}\$ 25-\$ 50 \text { range; } \mathrm{AZ}, \mathrm{LA}=\$ 25 ; \mathrm{SC}=\$ 26 ; \mathrm{CA}= \\
\$ 30 ; \\
\mathrm{MN}=\$ 40 ; \mathrm{MD}=\$ 50 . \text { Given before actigraph } \\
\text { compliance verified }\end{array}$ & $\begin{array}{l}\$ 25-\$ 40 \text { range; } \mathrm{LA}, \mathrm{SC}=\$ 25 ; \mathrm{AZ}, \mathrm{CA}, \mathrm{MN}=\$ 40 ; \\
\mathrm{MD}=\$ 50 . \text { Given after actigraph compliance } \\
\text { averified }\end{array}$ & 3 \\
\hline Fitness measure incentive $e^{\dagger}$ & $\begin{array}{l}\$ 5-\$ 20 \text { range; } \mathrm{CA}, \mathrm{LA}, \mathrm{MD}=\$ 5 ; \mathrm{SC}=\$ 10 \\
\mathrm{AZ}=\$ 15 ; \mathrm{MN}=\$ 20\end{array}$ & Not conducted in $8 \mathrm{~B}$ & 3 \\
\hline \multicolumn{4}{|l|}{ Consent form return/follow-up } \\
\hline $\begin{array}{l}\text { Girls complete and return assent forms } \\
\text { at presentation }\end{array}$ & SC: 3 or 4 schools only & SC: all schools & 3 \\
\hline Consent form return timeline & Varied by site: 1 day to 1 week & 1 day to 1 week; more stringent timeline & 3 \\
\hline \multirow[t]{2}{*}{ Consent return incentive } & $\begin{array}{l}\text { Girl: } \$ 0-\$ 5 \text { range; } \mathrm{CA}, \mathrm{MD}=\$ 0 ; \mathrm{MN}=\$ 1 \\
\quad \mathrm{AZ}, \mathrm{SC}=\$ 3 ; \mathrm{LA}=\$ 5\end{array}$ & $\begin{array}{l}\text { Girl: } \$ 0-\$ 5 \text { range; } \mathrm{AZ}, \mathrm{MD}=\$ 0, \mathrm{MN}=\$ 1 ; \mathrm{SC}= \\
\quad \mathrm{CA}, \mathrm{LA}=\$ 5\end{array}$ & 3 \\
\hline & Parent: N/A & Parent: SC only $=\$ 10$ & 3 \\
\hline $\begin{array}{l}\text { Face-to-face participant follow-up } \\
\text { by TAAG staff }\end{array}$ & $\begin{array}{l}\text { Periodically; location varied by site/school } \\
\text { (lunchroom, homeroom, PE classes) }\end{array}$ & $\begin{array}{l}\text { Periodically; location varied by site/school } \\
\text { (lunchroom, } \\
\text { homeroom, PE classes) }\end{array}$ & 2 \\
\hline Follow-up by school liaison & $\begin{array}{l}\text { AZ, CA, SC: periodically—helpful in collecting } \\
\text { straggler forms }\end{array}$ & $\begin{array}{l}\text { AZ, CA, SC: periodically—helpful in collecting } \\
\text { straggler forms }\end{array}$ & 2 \\
\hline $\begin{array}{l}\text { Automated phone message reminders } \\
\text { to parents }\end{array}$ & SC (4 schools only toward the end of recruitment) & $\begin{array}{l}\text { SC ( } 5 \text { schools only right before or day of } \\
\text { recruitment } \\
\text { presentation) }\end{array}$ & 2 \\
\hline School PA system announcements & $\mathrm{AZ}, \mathrm{LA}, \mathrm{MD}, \mathrm{MN}, \mathrm{SC}$ & $\begin{array}{l}\text { Utilized more frequently than in } 8 \mathrm{~A}: \mathrm{AZ}, \mathrm{MD} \text {, } \\
\text { MN, SC; } \\
\text { CA: daily for the week postpresentation }\end{array}$ & 2 \\
\hline \multirow[t]{2}{*}{ Primary method of consent form return } & $\begin{array}{l}\text { In-person returns to TAAG staff or school liaison: } \\
\text { AZ, CA, LA, MD, SC }\end{array}$ & $\begin{array}{l}\text { :In-person returns to TAAG staff or school liaison: } \\
\text { AZ, CA, LA, MD, SC }\end{array}$ & 2 \\
\hline & Returns via US mail: MN & Returns via US mail: MN & 2 \\
\hline \multirow[t]{2}{*}{ Consent form follow-up distribution } & Mailed: AZ, CA, MN, SC & Mailed: AZ, CA, MN & 2 \\
\hline & $\begin{array}{l}\text { Hand-delivered: LA, CA } \\
\text { AZ: Done by school liaisons at } 3 \text { schools; others }\end{array}$ & $\begin{array}{l}\text { Hand-delivered: LA, SC } \\
\text { AZ: Done by school liaisons at } 3 \text { schools: others }\end{array}$ & $\begin{array}{l}2 \\
2\end{array}$ \\
\hline Personal phone calls to parents & $\begin{array}{l}\text { AZ: Done by school liaisons at } 3 \text { schools; others } \\
\text { sites: } \\
\text { as needed to track down straggler forms or get } \\
\text { missing information }\end{array}$ & $\begin{array}{l}\text { AZ: Done by school liaisons at } 3 \text { schools; others } \\
\text { sites: } \\
\text { get as needed to track down straggler forms or } \\
\text { get missing information }\end{array}$ & 2 \\
\hline
\end{tabular}

* Rating key: 1 = not effective; 2 = moderately effective; 3 = very effective (indicates the effectiveness of this technique in recruiting eighth-grade girls, and reflects the site rating of the $8 \mathrm{~B}$ strategy compared to the $8 \mathrm{~A}$ strategy). This rating was provided by site representatives who were heavily involved in the recruitment process. Displayed rating is based on mode of ratings provided by sites that utilized the measure.

${ }^{\dagger}$ The general measurement incentive was given after successful completion of 2 surveys, physical activity monitor component, and height, weight, and skin fold measures, The fitness measure involved a bike test (only administered to a subsample of girls in 8A). 


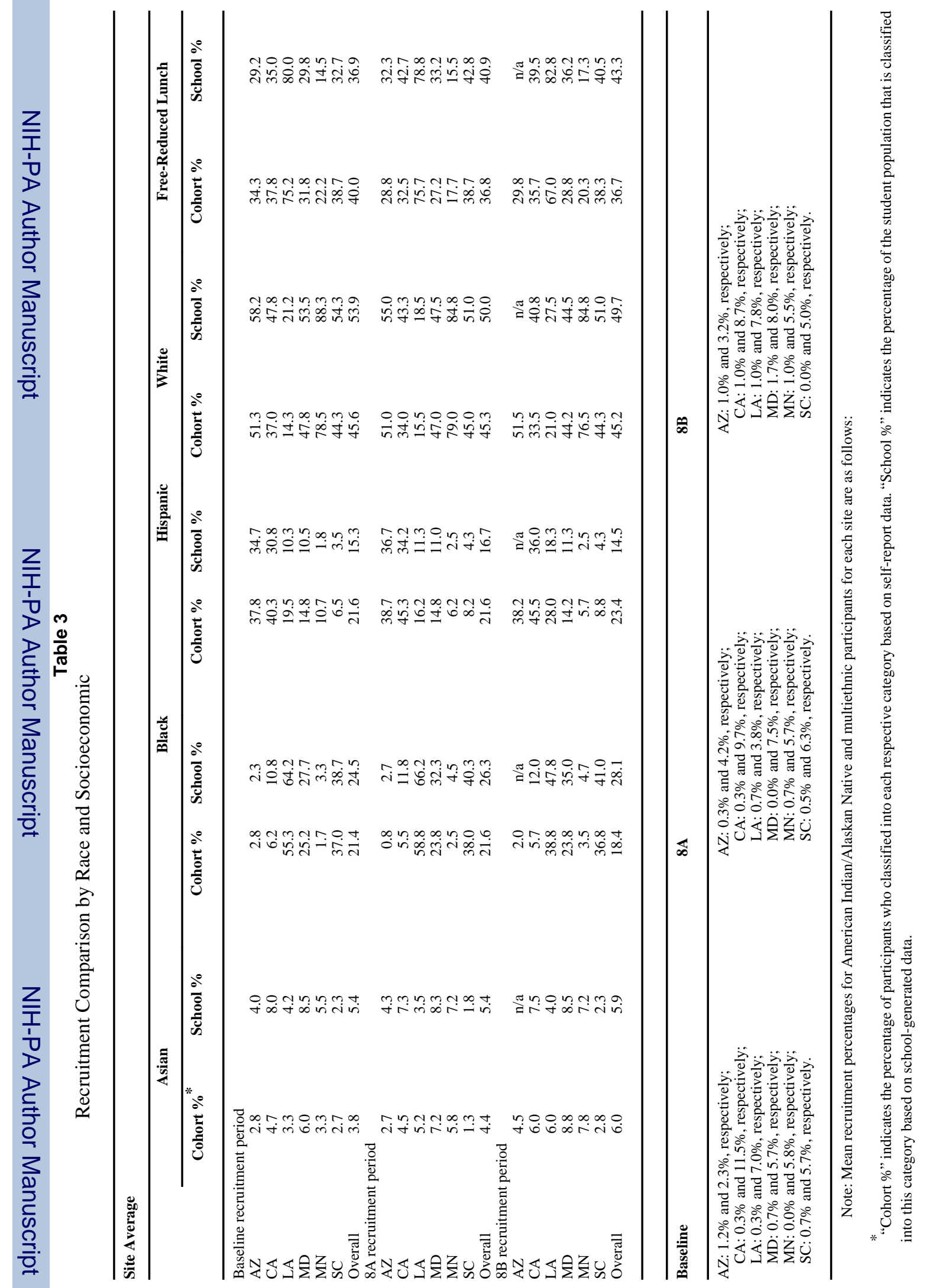

J Sch Health. Author manuscript; available in PMC 2009 October 20. 